ISSN 2663-0575 (Print)

ISSN 2663-0583 (Online)

Access to Justice in Eastern Europe,

Issue 2/3 (7) 2020

http://ajee-journal.com

10.33327/AJEE-18-3.2-3

$V$ Vébraite 'Impact of the COVID-19

pandemic on court proceedings in

Lithuania' (2020) 2/3 (7)

Access to Justice in Eastern Europe 156-159.

10.33327/AJEE-18-3.2-3-n000032

\title{
IMPACT OF THE COVID-19 PANDEMIC ON COURT PROCEEDINGS IN LITHUANIA ${ }^{*}$
}

\author{
Vëbraitè Vigita \\ PhD (Law), Assoc. Prof. at Faculty of Law, \\ Vilnius University, Lithuania
}

Summary: 1. Introduction. - 2. Court Proceedings during Lockdown. - 3. Conclusion. Lessons to be Learned.

The pandemic of coronavirus COVID-19 has impacted almost all areas of life through out the word. Justice system in Lithuania was no exception. The effects of the pandemic have been felt till now (the article was finished at the end of August), even if the lockdown was ended on the $16^{\text {th }}$ of June and until now country remains under the conditions of an emergency situation. This article will describe the most important effects of the pandemic to the court proceedings in Lithuania and what lessons could be learned from this situation.

Key words: COVID-19, civil justice, 'hybrid' hearing, court proceedings, online justice.

Received: 20.08.2020. Revised: 24.08.2020. Approved: 26.08 .2020

(C) 2020 Access to Justice in Eastern Europe and Vigita Vèbraite.

This work is licensed under a CC BY NC ND 4.0 license.

This is an Open Access publication distributed under the terms of the Creative Commons Attribution 4.0 International License, which permits to copy and distribute the material in any medium or format in unadapted form only, for noncommercial purposes only, and only as long as attribution is given to the creator. 


\section{INTRODUCTION}

Quarantine was introduced in Lithuania on the 16th of March, 2020. ${ }^{1}$ Art. 3.2.1. of the resolution stated that 'State and municipal institutions and bodies and state and municipal enterprises organize their work and provide customer services remotely, except where the functions (tasks) concerned must be performed at the workplace. The performance of urgent and immediate functions (tasks) shall be ensured'. Such regulation meant that most court cases in civil, criminal, or administrative matters had to be adjourned or heard remotely.

It must be mentioned that the courts in Lithuania have not been quite modernized until the pandemic, especially courts, which hear civil cases. Already in year 2004 a unified information system of Lithuanian courts LITEKO was launched. This system is being modernized all the time. From 1 March 2013, Art. 175 (2) of the Code of Civil Procedure ${ }^{2}$ came into force and legitimized the use of information and communication technologies (videoconferences, teleconferencing, etc.) during court hearings. Still, it can be said that this option had not often been used for civil cases until the pandemic.

A similar situation could be found for administrative proceedings. It has been possible already for seven years for citizens and companies to deliver and receive documents of the administrative and administrative offenses cases, to listen to the records of the court hearings and to pay stamp-duties and fines without leaving their residences. The situation was not so developed regarding criminal cases.

\section{COURT PROCEEDINGS DURING LOCKDOWN}

In Lithuania there has been no special legislation for court proceedings regarding COVID-19 pandemic. It has been believed that the legal norms of codes of procedure (concerning possibilities to hear cases via technological means) is enough to apply them for quarantine conditions also. The judicial Council only introduced recommendations for how court proceedings should look like during the quarantine and later. ${ }^{3}$

It was recommended during the quarantine to adjourn all scheduled hearings in oral procedure, except in cases of statutory urgency (for example, issues related to arrest, removal of a child from an unsafe environment). In urgent cases oral hearings had to be organized in the manner and time prescribed, taking all precautionary measures relating to the prevention of the spread of COVID-19, while maintaining a maximum distance between the participants in the courtroom. Otherwise, if it was possible and the parties to the disputes agreed, written procedure could have been applied, or court hearings could have been organized remotely, by means of technology.

After the quarantine had been introduced, all courts strived to work through different platforms (like Zoom or Teams). In several weeks the setting up of the hard- and

1 Government resolution No. 207 (14 March 2020) <https://lrv.lt/uploads/main/documents/files/ Nutarimas\%20Nr_\%20207\%20su\%20pakeitimais\%2004_30_EN.pdf> accessed 10 August 2020.

2 Valstybès žinios [2002] No. 85-4126.

3 All recommendations can be found online here: <https://www.teismai.lt/lt/naujienos/teismu-sistemosnaujienos/del-teismu-darbo-organizavimo-karantino-laikotarpiu/7444> accessed 10 August 2020. 
software to enable all judges to work from their homes was finished. Also, the complete staff of the courts worked from their homes during the lockdown.

The statistics of the national courts administration show that during lockdown 32 pct fewer new cases were received in the first instance cases than in the year 2019 in that period. Also, courts of appeal instance received 40 pct fewer of appeals in comparison with the year $2019 .{ }^{4}$

Almost all cases, which could have been heard in written procedure, have been finished in time (especially in appeal and cassation instances). Most of the cases, which had to be heard orally, because it was not possible to use written procedure, have been adjourned to the months of summer or autumn. More than 1100 court hearings have been organized through videoconferencing in three months. Most of these cases were civil, especially commercial matters. Some cases, where witnesses had to be heard in person, were adjourned as the court and the participants of the proceedings did not think it was possible to hear witnesses safely through electronic means.

Some mediation procedures have also been organized online and some of them were successful. It can be mentioned that at the beginning of 2020 mandatory mediation was launched in Lithuania as a prerequisite to contentious family legal actions in court. Enforcement procedure and communication between bailiffs and courts have been conducted electronically for several years already.

The situation was much more problematic with criminal cases. Most of them have been adjourned and are being heard during summer or later in autumn. Amendments to the Code of Criminal Procedure have been presented to allow the use of technological means more broadly for criminal cases also. Until the amendments came into force it had only been possible to hear witnesses or expert witnesses via videoconferences in criminal cases.

\section{CONCLUSION. LESSONS TO BE LEARNED}

As pandemic is still ongoing and nobody knows what the situation will be later this year, still some cases are being heard online in Lithuania and some mediations are also done online. Also, it can be agreed that some new types of cases could reach courts in near future ${ }^{5}$. There are already several claims in Lithuania regarding the declaration of quarantine and the damages it caused to private businesses; also, several plaintiffs have already sued hospitals because they have gotten infected with the virus at the hospitals.

The ongoing pandemic taught us that it is possible to have court hearings virtually, only proper equipment is needed. Also, judges, other staff in courts, lawyers,

$4 \quad$ More statistics on activities on courts during quarantine can be found online here: ,Lietuvos teismai karantino laikotarpiu - bylų nagrinèjimas persikèlè i elektroninę erdvę, organizuota daugiau nei tūkstantis nuotolinių posėdžių (7 July 2020) <https://www.teismai.lt/lt/lietuvos-teismai-karantinolaikotarpiu-bylu-nagrinejimas-persikele-i-elektronine-erdve-organizuota-daugiau-nei-tukstantisnuotoliniu-posedziu/7764> accessed 10 August 2020.

5 Opinion of Consultative Council of Judges (CCJE), ,The Functioning of Courts in the aftermath of the Covid-19 pandemic $<$ https://www.coe.int/en/web/ccje/-/functioning-of-courts-in-the-aftermath-ofthe-COVID-19-pandemic $>$ accessed 10 August 2020. 
prosecutors, and litigants should have the knowhow to use digital tools. Investing in new forms of dispute resolution should be an important priority for the government and the court system itself.

Such a 'hybrid' way of hearing cases could shorten time limits for court proceedings and make proceedings even more approachable for the public. Perhaps nobody could have anticipated that online court hearings would become quite normal so quickly. Many practitioners and scholars thought it would take more time to get used to the concept of online hearings.

Understandably, during an online hearing all the procedural rights of the participants of the proceedings must be safeguarded. While virtual hearings can work in a justice system, we cannot consider them a 'new normal' without providing the same safeguards a defendant would have, if they appeared in person, this is especially important for criminal cases. 